\title{
Moving towards a European Defence Industry? The Political Discourse on a Changing Reality and its Implications for the Future of the European Union
}

\author{
ANDRÉ BARRINHA
}

Since the Maastricht Treaty in 1992 the European Union has been an increasingly important actor in the field of security and defence. However, the defence industries sector has largely been kept away from Brussels. This has usually been justified by the role that national defence industries have traditionally played as fundamental pillars for the survival of the European nation-states, thus making them reluctant to share this "sovereign tool" with the European Union. Nonetheless, recent steps in both the economic (large number of mergers and acquisitions within the European defence industry sector) and the political (security and defence integration measures within the European Union) arenas have contributed to changes in the political discourse on defence industries within the European space. This article aims to explore how the national discourse on defence industries has become interrelated with a European discourse on the topic-a European discourse that mixes some of the old national arguments with particular aspects related to the constant evolution of the European Union towards an ever more coherent regional polity and international actorness. Also analysed is the extent to which this political move puts at risk the European Union's ambitions to promote a better world, based on an alternative understanding of international politics.

\section{Introduction}

Sixty years after the triggering of the European integration process, with the creation of the European Coal and Steel Community (1951), Europe is centred on a regional organisation that has increasingly incorporated state-like powers in its progression towards global actorness. In its quest for global affirmation, the European Union has been developing competences in a number of areas traditionally associated with the nation-state, such as foreign policy, security and defence. The European Union's ambitions in the field of security and defence are particularly relevant as these are competences usually attributed to the nation-state. Recent years have, indeed, seen the European Union adopting a whole myriad of measures within the field, such as the European Security and Defence Policy (ESDP). The ESDP was launched in the 1999 Helsinki European Council and officially considered operational four years later, in 2003. In the same year, the European Security Strategy was approved, highlighting the 
European Union's responsibility as an "inevitable" global actor, ${ }^{1}$ and putting forward a series of challenges the European Union faced, complemented by the main lines of actions it should follow to tackle those challenges. ${ }^{2}$

Since then, several measures have been adopted within the ESDP (Common Security and Defence Policy since the adoption of the Lisbon Treaty), such as the undertaking of several peace operations in different countries and continents (the European Union is undertaking, or has undertaken, 23 different military and civilian missions within the framework of the ESDP $/ \mathrm{CSDP}^{3}$ ), as well as the constitution of new military forces (the EU Battle Groups being the latest innovation in that matter ${ }^{4}$ ). Parallel to these measures, the European Union has been working on the establishment of a European defence industrial base and market, having created the European Defence Agency (EDA) for this purpose in 2004..$^{5}$ This way, the European Union intends to be able to have both the military might associated with a global power and the capacity to produce it within its own borders.

As mentioned above, this assumes an extraordinary relevance as this link between using and producing its own security and defence equipment is traditionally at the base of the affirmation of the sovereign state. By replicating this step, the European Union is moving towards its own affirmation as a polity that bases its legitimacy on the ownership of sovereign tools of power. This raises questions about both the "distinct approach" of the European Union in the international system ${ }^{6}$ as well as about its normative credentials. ${ }^{7}$

The focus of this article is on the underlying rationale that politically ${ }^{8}$ justifies the need on the part of Brussels to "upgrade" national defence industries to the European level. It will be argued that this political understanding is not particularly different from the traditional national justifications for keeping defence industries under the control of states. On the contrary, it implies the same "existential condition" in which the state (in this case the European Union) needs a defence industrial support in order to survive. In that sense, it will be argued that despite the calls for novelty, the construction of a European-wide polity is, at least in this area, related to the maintenance of the same defence-industry logic attached to an existential condition of survival.

This article will begin with the construction of a typology of arguments that have classically constituted the political discourse for the preservation of national

1. "A Secure Europe in a Better World" (Brussels, 12 December 2003), available: < http://ue.eu.int/ uedocs/cmsUpload/78367.pdf>.

2. Ibid.

3. "Overview of the Missions and Operation of the European Union" (May 2010), available: <http:/ / www.consilium.europa.eu/showPage.aspx?id=268\&lang=enhttp:/ / www.consilium.europa. eu/showPage.aspx?id=268\&lang=en $>$.

4. These Battle Groups (BGs) are composed of 1,500 soldiers, capable of intervening in a conflict theatre for 30 days without any extra support. These BGs can either be composed exclusively of national forces or be part of a multinational contingent. EU Council Secretariat, "EU Battlegroups Factsheet" (November 2006).

5. Council of the European Union, "Council Joint Action 2004/551/CFSP of 12 July 2004 on the Establishment of the European Defence Agency", Official Journal of the European Union (2004).

6. Javier Solana, "The Future of the European Union as an International Actor" (2005), available: <http://www.consilium.europa.eu/uedocs/cms_data/docs/pressdata/en/articles/84349.pdf>.

7. Ian Manners, "Normative Power Europe: A Contradiction in Terms?", Journal of Common Market Studies, Vol. 40, No. 2 (2002), pp. 235-258.

8. As this article is focused merely on the political justification and political understanding of defence industries, the views of the industry itself will not be contemplated here. 
defence industries. Political-military and economic reasons have traditionally been advanced to support such a position. In both cases there is an "existential" condition attached to the need for preserving these industries at the national level.

It will then analyse how, particularly after the end of the Cold War, this national discourse has been affected by "normalising" market dynamics, in the sense of making the defence market more similar to the neoliberal market dynamics that predominate in almost all the other areas of the international economy.

The article will then move on to its core focus, the European case, where those "normalising" dynamics have also been felt since the end of the 1990s, leading to the enhancement of the European political discourse on defence industries. Here, it will be seen how European states have been reacting to the changes in the defence industry, as well as to how the same existential arguments that have been justifying the maintenance of a national industrial base have been transferred to an increasingly predominant discourse favouring a European defence industry. This will be followed by an analysis of how the creation of the European Defence Agency, as well as of its predecessors, fits in this "Europeanising" logic and how it has been re-producing, in an even more affirmative way, the discourse within which it was created. The last section of this article will focus on the consequences the European Union has to face in terms of its constitution as a global actor, when stressing this need for a European defence industry.

\section{The National Logic of Defence Industries}

Defence industries have, in modern times, been associated with the state's role as the main actor in the international system. ${ }^{9}$ These industries helped fulfil the state's needs by being central actors in safeguarding the state's defence of its sovereignty. A political discourse encompassing political-military and economic arguments has been advanced to justify this strong relation between industries and states at the national level. The political-military argument has been constituted along three different justifications: autarky, arms control and deterrence. Regarding the economic argument, this has been linked to the influence these industries have on the economies of the countries in which they are based, as well as to the technological boost those same economies receive from the hightech products developed in the defence sector.

As just mentioned, the first political-military justification is associated with the ideas of "autarky" and with it the idea of "self-sufficiency". These two concepts are linked largely to a realist conception of international reality, in which the condition of anarchy determines that states privilege self-help in order to guarantee their own survival. ${ }^{10}$ In a world where no one can be trusted, to depend on arms imports makes a country vulnerable to potential supply cuts. ${ }^{11}$ As argued in The Economist, if a state does not control its own defence industry, other states might:

9. Keith Krause, Arms and the State: Patterns of Military Production and Trade (Cambridge: Cambridge University Press, 1992).

10. Kenneth Waltz, Theory of International Politics (New York: McGraw-Hill, 1979).

11. Richard Bitzinger, "Towards a Brave New Arms Industry?, Institute for International Institute for Strategic Studies, Adelphi Paper, No. 356 (2003), p. 11. 
Governments [...] insist that national security is at stake. Some of their concerns are understandable. A foreign takeover might allow sensitive military technologies, perhaps developed at great expense to the public purse, to escape into the wrong hands. ${ }^{12}$

The existence of a national defence industry is thus justified as the provider of a state's own military equipment. As advanced by Eugene Cobble, "The politics of weapons production is [...] intertwined with the very existence of the state itself." ${ }^{13}$ By providing a state with the tools (i.e. weapons) that guarantee its survival, the defence industry acquires an existential importance.

Related to this, but with slightly different nuances, is the "arms control" justification. Usually associated with the notion of proliferation and the general idea that the fewer weapons available globally the better, the "arms control" justification is applied to the case for a national defence industry in a much more self-interested way. In this particular context, defence industries are not only a crucial source of state survival but they can also be a key element in a state's foreign policy. ${ }^{14}$ The sale of military equipment is a form of power distribution in the international system. Hence, only by controlling the producers of military material it is possible to control who has access to it. It is necessary to take into consideration that this control is, in some cases, not only about restricting the sales but also about promoting them. For example, since 1961 the United Kingdom, following the United States, has had a division within the Ministry of Defence responsible for the promotion of British weapons abroad. ${ }^{15}$ This way, both the United Kingdom and the United States have the possibility to ensure that their companies' customers fit within each of these countries' strategic goals. Not controlling the producer means that the flow of military equipment is not distributed according to geopolitical priorities, but rather according to market dynamics.

The third political-military justification-deterrence-encompasses elements of the previous two. Deterrence, as argued in this article, is a concept that involves an aggressive behaviour and a passive attitude, that is, the demonstration of military power without using it. As highlighted above, national defence industries are taken as key elements in a state's survival and in its foreign policy. Such demonstration is supposed to contain both an external and an internal message. Externally, it shows the world that attacking that specific state has a very high cost; internally, it attempts to reinforce the cohesion between population and state by demonstrating the grandeur of the polity in which they exist-its symbolism feeds directly into the national imaginary, serving as a "legitimiser" of a state's sovereignty. ${ }^{16}$ For this, a strong defence industry can be seen being as important as having a strong military arsenal: the latter representing a state's effective military power, the former its capacity and potential to generate that military power. ${ }^{17}$

12. "Linking Arms", The Economist (12 June 1997).

13. Eugene Cobble, "Ideas, Identity and the Limits of European Defense Technology Cooperation", in Judith Reppy (ed.), The Place of the Defense Industry in National Systems of Innovation, Occasional Paper 25 (Ithaca, NY: Cornell University Peace Studies Program, 2000), p. 131.

14. Keith Hayward, "The Globalisation of Defence Industries", Survival, Vol. 42, No. 2 (2000), pp. $115-132$ (p. 127).

15. "Odd Industry Out", The Economist (18 July 2002).

16. Cobble, op. cit., p. 151.

17. Bitzinger, op. cit., p. 15. 
In short, autarky, arms control, and deterrence are justifications fed by the statist notion of military security. As mentioned above, in addition to military security, defence industries are equally related to the sustainability of a state's economy. As stated by Pierre De Vestel,

[t]he investment of public funds in an economic activity is necessarily made with a view to the national economy gaining the maximum advantage, especially as the benefits in terms of jobs and technological progress are and will remain a powerful mean of justifying military expenditure in the eyes of the public. ${ }^{18}$

Be it for the jobs it creates or the mere proportion of a country's Gross Domestic Product (GDP), defence companies are often defined as essential to a country's economy. The use of high technology makes defence companies important for another reason-the potential dual use of that technology in "civil" industries and the registering of their patents nationally. According to Richard Bitzinger, "[i]n addition to fulfilling perceived requirements for self-sufficiency, arms production has often been seen as an important mechanism for driving a country's overall economic development and industrialisation". ${ }^{19}$ The economic dimension is nonetheless highly distorted by the central role that states play in the defence industry. The defence industry is about the only economic activity that has governments as quasi-exclusive customers. ${ }^{20}$ In that sense, market forces do not work as in other industries. ${ }^{21}$ The end result is that security of supply and political-military criteria take precedence over efficiency and economies of scale. Countries that in other spheres are quite willing to see national industries de-localise their production to other countries and be acquired by other companies, assume a clear protectionist position when it comes to defence industries. For example, just a week after signing a declaration regarding the need to open its defence markets to cross-border competition, Germany tried to block a French company from buying Atlas Elektronik, a German defence firm ${ }^{22}$ to prevent a foreign company controlling a national one, even if that company was based in one of its strongest allies.

Thus, both the economic weight and technological development justifications lead to an understanding of these industries as fundamental for the guaranteeing of a state's economic security. The enemy is unknown, but the threat is clear: unless the state has an internationally competitive economy, its independence and even existence will be at stake. In that sense, defence companies are essential not only to a state's military security but also to its economic security.

In short, there is an intimate relation between the state and the defence industry, supported by a multi-dimensional existential discourse that has historically constructed the national framework as the key element in the defence business. ${ }^{23}$

18. Pierre De Vestel, Defence Markets and Industries in Europe: Time for Political Decisions?, Chaillot Papers, Institute for Security Studies, Western European Union, No. 21 (1995).

19. Bitzinger, op. cit., p. 13.

20. "Odd Industry Out", op. cit.

21. Ulf Hammarström, "Up and Running", EDA Bulletin (December 2006).

22. "Consolidate or Die", The Economist (1 December 2005).

23. Erik Kopac, "Defense Industry Restructuring: Trends in European and U.S. Defense Companies", Transition Studies Review, Vol. 13, No. 2 (2006), p. 283. 


\section{Winds of Change}

With the end of the Cold War, the world was left with a surplus of weapons and the capacity to produce them ${ }^{24}$. What emerged after the end of the Cold War was "a business worth around $\$ 200$ billion worldwide in which America dominates, Europe trails behind and the rest of the world is just a collection of mostly outdated industries or subcontractors to the Americans". ${ }^{25}$

Without a clear threat, defence budgets were reduced while the production of defence equipment was becoming more expensive. Together with the 1990s globalisation dynamics-where national security was now secondary in an interconnected, conflict-absent (with the exception of internal conflicts in the periphery of the international system) world-the relation between state and defence industry faced new questions. For instance, defence companies started to demand more exports, as a form of compensation for the shrinking of national orders. Underlying this was the idea that more exports would allow the industry to survive, as the resulting visible economies of scale for each product would make such products cheaper. ${ }^{26}$ In the United States, a large number of defence-specialised companies were slashed (by mergers and acquisitions) in the early 1990s with the active support of the Clinton administration. ${ }^{27}$

For Michael Portillo, the fact that the United Kingdom was the second largest exporter after the United States showed that Britain had "everything to gain from a genuinely open defence equipment market" ${ }^{28}$ It is interesting to note that exporting defence goods in a large scale was taken by the former British Secretary of State for Defence as something positive and desirable; there was no major consideration for the controlling of the arms trade or for the potential dangers of flooding the international system with defence equipment. The only strategic rationale at work was, and still is, the one that links the state with the benefits of competitive industries.

Such logic seems to persist, as industries become more detached from states. For General Vincenzo Camporini, the Italian Chief of General Defence Staff, the tendency is for the two to become increasingly separate. According to him

there has been a continuous loosening of ties between defence industries and national governments [...] Increasing complexity in manufacturing processes together with the development of ever-closer links with the civil sector have resulted in the concentration of production capacity and pursuit of cooperative ventures outside the

24. Bitzinger, op. cit., p. 5.

25. "Transformed?", The Economist (18 July 2002).

26. John Lovering, “The Defense Industry as a Paradigmatic Case of 'Actually Existing Globalization'", in Reppy, op. cit., p. 33.

27. In 1997, with only five big companies left (Lockheed Martin, Boeing, Northrop-Grumman, General Dynamics, and Raytheon), the Clinton administration opposed a further merger between Lockheed Martin and Northrop-Grumman on the grounds that it would "eliminate effective competition in a number of weapons lines". Ann Markusen, "Should we Welcome a Transnational Defence Industry?", in Reppy, op. cit., p. 30.

28. Michael Portillo, "Foreign Affairs and Defence", Michael Portillo, Official Website, 16 November 1995, available: <http://www.michaelportillo.co.uk> . 
national environment where demands often prove economically insufficient. $^{29}$

Whereas national defence companies used to obey a national production and weapons performance logic, such a tendency seems to have shifted to a preoccupation with economies of scale. ${ }^{30}$

The commodities being traded are also an example of such changes. It is no longer just about ships, planes or armoured vehicles, but also about spare parts, where the more technology-sensitive material is expected to stay with the original producer (and all the other material is to be spread across a complex web of producers $^{31}$ ).

Such a focus on technology raises some other questions, though. One of them is related to the state-of-the-art technology increasingly being held in civilian companies, rather than military ones. ${ }^{32}$ This makes it more difficult to control the access to technology (particularly dual-use technology), as well as to guarantee the security of supply. Such a tendency is also leading to the globalisation of the supply chain and the de-nationalisation of the defence components. ${ }^{33}$ As highlighted by the Deputy National Armaments Director of the Armaments Agency of the French Ministry of Defence, "The international nature of this flow of capital sometimes makes it difficult to identify the notions of a company's 'nationality' - a consideration so important in the defense sector." ${ }^{\prime 34}$

Also, particularly after $9 / 11$, there seems to be a tendency for defence companies to start investing in internal security, blurring the distinction between "security" and "defence". As argued by the Stockholm International Peace Research Institute (SIPRI), many military electronics companies are moving exactly in that direction, transforming themselves into "defence and security companies". ${ }^{35}$ According to the Financial Times, in the face of decreasing defence budgets and increasing investment in security equipment, these companies seem quite eager to expand their areas of activity, while attempting to merge security and defence equipments in order to better accommodate their interests. ${ }^{36}$

However, this is not uncontrolled globalisation. These suppliers, even though more spread, are part of a small number of big American and European companies that still dominate the market. According to SIPRI, in 2005, companies based in the United States corresponded to $63 \%$ of the top 100 arms sales, while Western European companies accounted for $29 \%$, and Russian companies for $2 \%$, the remaining $6 \%$ being divided mainly between Japan, Israel and India. ${ }^{37}$

29. Vincenzo Camporini, "Policies of European Defence Industries—or European Industrial Defence Policies?", RUSI Defence Systems (Summer 2006), p. 28.

30. "A Farewell to Arms Makers", The Economist (20 November 1997).

31. Paul Cornish, The Arms Trade in Europe, Chatham House Papers (London: Royal Institute of International Affairs, 1995), p. 62.

32. Judith Reppy, "Preface", in Reppy, op. cit., p. 5.

33. Hayward, op. cit., p. 118.

34. Patrick Auroy, "The French Approach to a European Defense Industrial Base", European Affairs (Summer/Fall 2007).

35. Elisabeth Sköns and Eamon Surry, "Arms Production", in SIPRI Yearbook 2007: Armaments, Disarmament and International Security (Oxford: Oxford University Press, 2007), p. 346.

36. James Boxell, "UK Homeland Security: Companies Seek Fresh Source of Income”, Financial Times (8 September 2009).

37. Sköns and Surry, op. cit., p. 347. 
Also, whereas in 1990 the world's top 10 companies were responsible for $37 \%$ of global weapons sales, 10 years later, in 2000, that number had reached $58 \% .^{38}$ Companies are thus consolidating under the idea that "bigger is better and biggest is better still". ${ }^{39}$

In short, the trend indicates that we might be heading towards a defence industry with fewer but bigger companies, more detached from individual states, producing products that serve both defence and internal security requirements.

After having surveyed the latest global trends in the defence industry, the focus will now turn to the changes that have developed specifically within the European context.

\section{Defence Industries and European Security}

Since the 1950s there has been a consistent clash between the European integrative dynamics that have increasingly affected all economic sectors of the "Old Continent" and the Member States' persistence in keeping defence industries at the national level. According to Keith Hayward:

The main concern of Western governments, particularly during the Cold War, was to stay ahead of the Soviet Union and other potential adversaries. However, increasingly for many Western European states, a key objective was to retain a degree of autonomy in arms development and production for national industrial reasons. ${ }^{40}$

Hence, when the US industry started consolidating in the early 1990s, Europe's defence industry was a "collection of national defence fiefdoms", ${ }^{41}$ with consolidation coming mainly under the form of national companies acquiring other smaller national companies (creating the so-called "national champions"). Relations with other countries' industries were limited, particularly within the European space.

By the end of the 1990s, though, the European defence industry had initiated a deep reform process, unfolded in parallel with the maintenance of a certain idea of a national defence industry. The result was that, in a few years, the European defence industry "transformed itself from a collection of medium-sized, nationally orientated firms to one dominated by two giants, with several smaller firms closely linked to these leaders". ${ }^{2}$ According to a RAND Corporation report produced by Katia Vlachos-Dengler, ${ }^{43}$ the process followed three distinct models. First, the already mentioned consolidation of national champions: the merger between British Aerospace and GEC Marconi-two British companies-that led

38. Terrence Guay, The Transatlantic Defense Industrial Base: Restructuring Scenarios and their Implications, Monograph (Carlisle, PA: Strategic Studies Institute, 2005), p. 7.

39. Hayward, op. cit., p. 120.

40. Ibid., p. 116.

41. Guay, op. cit., p. 4.

42. Terrence Guay and Robert Callum, "The Transformation and Future Prospects of Europe's Defence Industry", International Affairs, Vol. 78, No. 4 (2002), p. 757.

43. Katia Vlachos-Dengler, From National Champions to European Heavyweights. The Development of European Defense Industrial Capabilities across Market Segments, Documented Briefing (Santa Monica: RAND, 2002). 
to the creation of BAE Systems (one of the two current European giants) is a good example of this national consolidation. Second, the consolidation at the European level, such as the creation of the other European giant-the European Aeronautic Defence and Space Company (EADS) — was in that context the symbol of this European consolidation. EADS became the junction of the German DaimlerChrysler with a French holding company jointly owned by the French government and the Lagardére conglomerate. Each one of these two sides has around 30\% of the company. Five per cent belongs to the Spanish government's leftover of Construcciones Aeronáuticas, S.A. (CASA). The remaining 30\% is traded on the Amsterdam stock exchange. ${ }^{44}$ The third and last model was the expansion of individual firms, integrating smaller businesses, such as the French company Thales that integrated a number of smaller French companies.

These consolidation processes had and still have to deal with a very nationaloriented mindset. According to the European Commission, ${ }^{45}$ Member States spend, on average, almost $85 \%$ of their equipment budget within their borders. As Daniel Keohane highlights: "[d]efence remains the most 'national' of all policy areas, in the sense that the EU member states are very reluctant to give up sovereignty to international organisations". ${ }^{46}$ This has led to what Katia Vlachos-Dengler calls "the European spaghetti bowl" ${ }^{47}$ in which several different forms of business relationships (joint ventures, consortia ...) are established between an already complex set of national (states, companies), transnational (companies) and international actors (international organisations).

In general, there were four different types of relationship being established in Europe between governments and industry during this period. ${ }^{48}$ First, countries with "special" relations with their national champions; second, countries with a strong involvement in the defence industry, but not at the level of shareholders, and willing to be open to competition; third, countries with niche capabilities that try to preserve them; and, finally, countries with limited or no defence industrial capacity, which sometimes have dual-use assets that can be spun in.

However, the weight of the "national factor" on the industry seems to be increasingly secondary. Through mergers and acquisitions, companies in this sector achieve economies of scale that lead to higher turnovers than those that individual countries can afford. According to General Vincenzo Camporini, the Italian "national champion" Finmeccanica has an annual turnover that doubles Italy's defence equipment budget. As he concludes: "the outcome of this type of situation is reduced bargaining power on the demand side and with it a weakened ability to influence the policies of industrial conglomerates" ${ }^{49}$ For the Italian Chief

44. "Getting it Together?", The Economist (18 July 2002).

45. European Commission, A Strategy for a Stronger and More Competitive European Defence Industry, Communication from the Commission to the Council, the European Parliament, the Economic and Social Committee and the Committee of the Regions (Brussels: Commission of the European Communities, 5 December 2007), p. 4.

46. Daniel Keohane, "Introduction", in Daniel Keohane (ed.), Towards a European Defence Market, Chaillot Paper No. 113 (2008), p. 6.

47. Vlachos-Dengler, op. cit., p. xi.

48. Jean-Pierre Darnis, Giovanni Gasparini, Christoph Grams, Daniel Keohane, Fabio Liberti, JeanPierre Maulny and May-Britt Stumbaum, Lessons Learned from European Defence Equipment Programmes, Occasional Paper No. 69 (Paris: Institute for Security Studies, 2007), p. 24.

49. Camporini, op. cit., p. 29. 
of Defence General Staff, if states are to maintain a say in the industry's dynamics, and if the latter is to remain attached to some sort of political-military rationale, it is necessary to have a European approach for an increasingly transnational issue. In short, General Camporini's suggestion is that it is necessary to transplant national control over these industries to the European level-attaching to them a political-military discourse that legitimises such control.

After briefly analysing the impact of the market dynamics in the specific case of European defence industries, this article will now focus on how that European discourse has been constructed, and institutionally sustained-with a particular focus on the creation of the European Defence Agency.

\section{Europe's Discourse on Defence Industries}

The common defence industry discourse at the European level has been present since the failed creation of the European Defence Community in the 1950s. In 1978, the European Parliament approved the Kepsch report in which the Commission was urged to propose a model for a Community market in defence equipment and an eventual Agency to oversee it. In reply, the Commission published the Greenwood report, where the lack of interest from national states in pursuing such a policy was highlighted. ${ }^{50}$

In the following year, at the Guadeloupe meeting, Chancellor Schmidt, President Giscard d'Estaing and Prime Minister Callaghan discussed the issue, reaching the conclusion that even though it made sense for each country to specialise in what they did best, and that competing programmes for the same type of platform did not make sense, these ideas were just "much too difficult to implement". 51

Things were to change, though. The adoption of the Single European Act, the end of the Cold War, and the revamping of the European integration process that would lead to the creation of the European Union offered "new and promising prospects" for those in favour of an integrated European defence market. ${ }^{52}$ The European defence market discourse was strongly enhanced, with the underlying assumption that something had to be done if Europe was to have a future in the global defence market.

With time, particularly with the advances in the area of security and defence, this European discourse evolved and became more complex, leading to five main justifications as to why Europe should have a common defence industry, some of them corresponding to the transfer of justifications from the national to the European level.

A first argument derives from the steps that have been taken regarding the establishment of a strong European Security and Defence Policy (ESDP). As made clear by Erkki Liikanen, former European Commissioner for Enterprise and the Information Society, "the competitiveness of the European defence industry is vital to our political and economic interests and to the credibility of the European Security

50. Terrence Guay, At Arm's Length: The European Union and Europe's Defence Industry (London: Macmillan, 1998), p. 45.

51. Nick Witney, Re-energising Europe's Security and Defence Policy, Policy Paper, European Council on Foreign Relations (London: European Council on Foreign Relations, 2008), p. 36.

52. De Vestel, op. cit., p. 1. 
and Defence Policy". ${ }^{53}$ The question here is one of "credibility" more than one of immediate threat. As the European Commission stated in a 2007 report:

[w] ith unchanged policies the European industry risks becoming a niche player, supplying mostly non-European prime contractors, thereby jeopardising the industrial capacities to autonomously develop the capabilities needed for the ESDP. ${ }^{54}$

To a large extent, such political justification is similar to the one advanced by individual states when they link defence industries to their own international credibility defined in terms of military power. It is about the European Union as a recognisable actor in international relations.

A second argument usually put forward in European circles is related to the transatlantic partnership. According to former NATO Secretary-General Lord George Robertson, for Europe and North America to be able to work together in achieving their common strategic goals there is "one essential foundation: a defence industrial marketplace that is open and competitive, and supported by a defence industrial base that is innovative and robust". ${ }^{55}$ Underlying this argument is the idea of the "Western front" in which Americans and European share common interests and values and that their international relations should have, as a starting point, this transatlantic partnership.

However, there is a third argument that points to the inversion of this transatlantic relationship by saying that US companies will dominate the European market if the Europeans do not decide to cooperate among themselves. This would have two major consequences. First, it would widen the technological gap between the two sides of the Atlantic ${ }^{56}$ and thus increase the already huge distance between North America and Europe in terms of military capabilities; ${ }^{57}$ second, Europe would become totally dependent on the United States for military equipment: "[t]here is a danger that European industry could be reduced to the status of sub-supplier to prime US contractors, while the key know-how is reserved for US firms." ${ }^{\prime 58}$ Both arguments are once again quite in line with what is reproduced at the national level. First, the idea of the technological advantages these industries bring to the economies in which they are based; second, the autarky argument, in which despite the strong ties with the United States, ultimately there is no one "we" (the European Union) can trust.

53. Erkki Liikanen, "The Role of the EU and European Commission Initiatives to Promote a Competitive European Defence Technological and Industrial Base", Forum Europe 5th European Defence Industries "Europe's New Defence Era" conference, Brussels, 23 May 2000.

54. European Commission, op. cit., p. 5.

55. George Robertson, "ESDI and Transatlantic Defence Cooperation", Speech by Lord Robertson, NATO Secretary General at "The Globalisation of Defence Industry: Policy Implications for NATO and ESDI" conference, Chatham House, London, 29 January 2001.

56. Björn von Sydow, Speech delivered by Björn von Sydow, Swedish Minister for Defence, at the "Defence and Security in an Uncertain World" conference, Brussels, 17 May 2002.

57. Honor Mahoney, "MEPs Urge Commission to Push Ahead in Opening up EU Defence Markets", EUObserver.com (2006), available: <http:/ / euobserver.com/?aid=22408>.

58. European Commission, Towards an EU Defence Equipment Policy, European Defence-Industrial and Market Issues, Communication from the Commission to the Council, the European Parliament (Brussels: Economic and Social Committee and the Committee of the Regions, 11 March 2003), p. 11. 
A fourth argument develops an economic approach to the issue: the duplication of national programmes, juste retour, and other "national" impositions leads to a waste of resources and money that could be better spent in a common defence market. As the European Commission put it: "[t]axpayers should get the most out of the investment they make in security". ${ }^{59}$ This argument has been present since at least the late 1970s, when the leaders of the major European countries agreed that a European approach to the defence industry was sensible but difficult to implement. It clearly highlights the higher efficiency in terms of defence spending that would derive from a more "common" defence industry. ${ }^{60}$

Finally, the last argument concerns the European project as an existential condition for its members. Here it is not just about more efficient spending but also about the future of Europe. In a 2007 speech, Javier Solana stated: "we [Europeans] must act soon, if a globally competitive European DTIB [Defence Technological Industrial Base] is to continue to exist". He would further add in a more dramatic rhetorical tone: "[w]e must realise that this is not merely a matter of economics, but it is a matter of the infrastructure of Europe's essential security". ${ }^{61}$ In this argument the European defence industry acquires an existential status: without it, "we" Europeans cannot survive. The "Group of Personalities" that in 2004 were invited by the European Commission to write a report on European Security Research has reinforced such a point by stating:

[g]iven today's security environment, there is an urgent necessity to act. The stakes are too high to trivialize threats, hoping that catastrophic events would spare EU territory. Europe must rapidly build up the capability to protect its citizens at home as well as to deploy significant resources for peacekeeping, humanitarian aid and institution-building activities abroad. To achieve these objectives, Europe must take advantage of its technological strengths. This requires state-of-the-art industries, a strong knowledge infrastructure, appropriate funding and an optimal use of resources. $^{62}$

In some cases, the discourse acquires fatalistic dimensions, as when the former Chief Executive of the European Defence Agency (EDA) metaphorically argued that "we [Europeans] are trying to climb the same mountain and we are all roped together"; 63 or when Javier Solana stated that the Europeans were "condemned to cooperate". ${ }^{64}$ Again, this is the type of argument that underlines the whole national discourse on defence industries: the latter are crucial for the survival of the former.

59. Ibid., p. 5.

60. Mahoney, op. cit.

61. Javier Solana, "Keynote Speech", EDA conference on the European Defence Technology and Industrial Base, Brussels, 1 February 2007.

62. The Group of Personalities (2004), Research for a Secure Europe: Report of the Group of Personalities in the Field of Security Research (Luxembourg: Office for Official Publication of the European Communities, 2004), p. 11.

63. Nick Witney, "Role of the Different Actors: Industry, National Governments, European Commission, European Defence Agency", "Défense 2006" Economist conference, Paris, 29 November 2005.

64. Solana, "Keynote Speech", op. cit. 
Put together, these five arguments constitute the discourse in favour of a European defence industry. These arguments have sustained (and been sustained) by a set of legal and institutional arrangements that since the 1970s have helped to shape European cooperation, integration and harmonisation in this field, and that have so far culminated in the creation of the EDA.

After briefly exploring this historical institutional evolution, the article will then focus on how to a large extent the EDA embodies the European discourse on defence industries, and of its problems in definitely overcoming the national tendencies that, despite the European and market tendencies, still fight to resist these changes.

\section{European Institutional Evolution in the Field of Defence Armaments Cooperation}

Since 1976 there have been some institutional arrangements at the European level related to the defence industry. This was the year in which the European members of the North Atlantic Treaty Organization (NATO) launched the Independent European Programmes Group (IEPG), that eventually evolved into the West European Armaments Group (WEAG), officially established in 1992 within the framework of the Western European Union (WEU). Its main role was to harmonise armament requirements, procurement procedures and research and development. However, it attracted limited interest from its members, never really influencing the sector. Another institution would follow: the West European Armaments Organisation (WEAO), created within the WEAG (but with its own legal personality since 1996). Again, it would have no more than a "relatively moderate impact". ${ }^{65}$

More successful was the Organisme Conjoint de Coopération en Matière $\mathrm{d}^{\prime}$ Armement (OCCAR ${ }^{66}$ ) formally created in November 1996, and later (in January 2001) upgraded to the status of independent organisation with a legal personality. The new feature of OCCAR was that it sacrificed, for the first time, the principle of juste retour-where all the countries that participate in a certain project have the right to industrial participation equivalent to the financial contribution. ${ }^{67}$ Instead, it followed the option in which the shares allotted to each member were defined according to the total set of OCCAR-managed projects and not on a programme-by-programme basis. ${ }^{68}$ The success of OCCAR, however, has been linked to its technical role in managing multinational projects, and, therefore, not as threatening to national sovereignties as the more politically ambitious WEAO has tried to be. ${ }^{69}$

Another measure in the field of the European defence industry was the 1998 Letter of Intent (LoI) signed between France, Germany, Italy, Spain, Sweden and

65. Kjell A. Eliassen and Nick Sitter, Arms Procurement in the European Union: Achieving Mission Impossible?, Report 4/2006 (Oslo: Centre for European and Asian Studies at the Norwegian School of Management, 2006), p. 6.

66. OCCAR originally comprised France, Germany, Italy and the United Kingdom, with Belgium and Spain joining in 2003 and 2005, respectively.

67. Ignacio Cosidó, La industria de defensa española ante la consolidación del sector en Europa, ARI No. 44 (Madrid: Real Instituto Elcano, 2005), p. 6.

68. Eliassen and Sitter, op. cit., p. 6.

69. Jocelyn Mawdsley, "Arms Agencies and Accountability: The Case of OCCAR", European Security, Vol. 12, No. 3-4 (2004), p. 102. 
the United Kingdom. Its main purpose was to support exports and transfers, and facilitate R\&D exchange between its signatories. However, as Daniel Keohane highlights, the LoI "did not have a major impact on cross-border armaments regulations, partly because it only aimed to help transnational companies to operate across borders, and did not establish a common market among the signatories". ${ }^{70}$ According to Nick Witney, in recent years it has become "little but a touring discussion club for officials unsupervised by ministers". ${ }^{71}$

The European Commission has increasingly been involved in the defence market, even though its reach was, and still is, limited by Article 296 of the EU Treaty that allows Member States to be safeguarded against any potential Commission attempt to regulate the market. According to 1(b) of this Article:

any Member State may take such measures as it considers necessary for the protection of the essential interests of its security which are connected with the production of or trade in arms, munitions and war material; such measures shall not adversely affect the conditions of competition in the common market regarding products which are not intended for specifically military purposes.

The increase of dual-use technologies applied to the defence sector, however, has led the European Commission to affirm its presence in the sector. Another sign of its presence has also been its Communications on the sector. In 1997, for example, the European Commission published a Communication entitled Implementing European Union Strategy on Defence-related Industries in which it highlighted that "National frameworks no longer have the capacity to achieve the scale of restructuring needed." As such, it argued that it was essential to create a "European framework to provide adequate solutions", which should eventually become "a source of rules governing a European market for armaments". ${ }^{72}$

Five years later, while the European Convention was preparing the eventually failed European Constitution, the Commission published another Communication: Towards an EU Defence Equipment Policy. Here, the same argument was reinforced, albeit in a more precise way, with the Commission defending the idea that the European Union should create a Defence Equipment Framework that included collaborative programmes, research and technology, and off-theshelf procurement. ${ }^{73}$

This proposal would be materialised in the creation of the European Defence Agency. At the EU Summit in Thessaloniki in June 2003 it was agreed to create the European Defence Agency as an intergovernmental agency working under the EU framework. Even though it was firstly supposed to be part of the European Constitution, it ended up being detached from it. ${ }^{74}$

The Council eventually established the European Defence Agency (EDA) on 12 July 2004. It was designed to support the Council and the Member States in their

70. Keohane, op. cit., p. 6.

71. Witney, Re-energising Europe's Security and Defence Policy, op. cit., fn. 6.

72. European Commission, Implementing European Union Strategy on Defence-related Industries, Commission Communication to the Council, the European Parliament (Brussels: Economic and Social Committee and the Committee of the Regions, 12 November 1997), p. 2.

73. European Commission, Towards an EU Defence Equipment Policy, op. cit., p. 7.

74. Eliassen and Sitter, op. cit., p. 2. 
effort to improve European defence capabilities in the field of crisis management and to sustain the ESDP as it stands now and develops in the future. The Agency was ascribed four functions: defence capabilities development; armaments cooperation; the European defence technological and industrial base and defence equipment market; and research and technology. The EDA was set up as an Agency of the European Union, with Javier Solana chosen as Head of the Agency and chairman of the Steering Board, which acts under the Council's authority and within the framework of guidelines issued by the Council. For the French Minister of Defence at the time, the EDA was the chance for Europe to "take control of its destiny". ${ }^{75}$

\section{The EDA as a Discursive Organising Core}

Even though limited by its intergovernmental status, ${ }^{76}$ in the last six years the EDA has been producing a substantial number of policies and recommendations. Also, it has constituted itself as a privileged forum where national defence ministers and armaments directors, Commission, Council, and industry meet and harmonise views. ${ }^{77}$ Potentially resulting from this, the EDA has been solidifying the discourse in favour of a more European defence industry. It has done so by producing a consistent view on the role of security and defence within the European Union and the place of the defence industry within it. In a sense, it has expanded the "existential condition" justification, and included all the other arguments within this one. The EDA has, in that matter, become the organising core within the European Union regarding a European discourse on defence industries. More than the ESDP, more than the potential positive or negative relations with the United States, and more than the mere economic rationale, Europe must unite for its own survival-this is no longer an option. As Nick Witney, the EDA's first Chief Executive, recognised: "it is no longer good enough to think just in terms of the national defence technological and industrial base"; it is necessary that "we [...] all start to think about the European industrial base as an entity in its own right". ${ }^{78}$

The Long Term Vision report published by the Agency in 2006 seems paramount in the harmonisation of the EDA's discourse in the sense that it constructs a particular context from which the EDA would develop its activities. Strategically, it speaks of unknown threats; regarding the defence industry, it presents a scenario in which "defence companies move progressively from government to private ownership" and where "shareholder funds become increasingly prominent in the control of companies". As a result "one may expect the normal laws of globalised economy to apply; capital will flow to optimise returns". ${ }^{79}$ With unknown threats and a globalised world interfering in the evolution of the European defence market, there is only one way forward for the EDA: "[t]he need, in

75. Michèle Alliot-Marie, "Taking the European Defence Industry Forward", Speech by Mme AlliotMarie at Colmar, French Embassy, London, 2005, available: < http://www.ambafrance-uk.org >.

76. Guay, The Transatlantic Defense Industrial Base, op. cit., p. 13.

77. Iraklis Oikonomou, "The EU Politico-military-industrial Complex. A New Research Agenda", Paper presented at the 31st BISA annual conference, University College Cork, 20 December 2006, p. 13.

78. Witney, Re-energising Europe's Security and Defence Policy, op. cit.

79. European Defence Agency, An Initial Long-term Vision for European Defence Capability and Capacity Needs (Brussels: EDA, 2006), p. 31. 
short, is to accept that the DTIB [Defense Technology Industrial Base] in Europe can only survive as one European whole, not as a sum of different national capacities". ${ }^{80}$

One year later Nick Witney would reinforce the point with a consensual rhetoric: "everybody knows that if Europeans want to preserve effective military clout, and a globally competitive industry, they have no choice but to cooperate" ${ }^{81}$ Exactly the same argument would be advanced by another EDA official in an article for RUSI Defence Systems. In the words of the EDA's Industry \& Market Director, Ulf Hammarström: "[m]ore interdependence is less an issue of choice than of necessity-all recognise that self-sufficiency is no longer an option in defence. Competitive industries can no longer survive within national borders" ${ }^{\prime 2}$

On 9 April 2008 the EU Member States asked the EDA to produce "an Armaments Strategy to help meet future military needs, ensure interoperability and standardization, and share the ever-increasing costs of developing and procuring high-technology defence equipment ${ }^{\prime \prime}{ }^{83}$ Some months later, in December, when revising the 2003 European Security Strategy, the Council officially highlighted the importance of the EDA in leading the process of creating a robust defence industry:

Experience has shown the need to do more, particularly over key capabilities such as strategic airlift, helicopters, space assets, and maritime surveillance [...] These efforts must be supported by a competitive and robust defence industry across Europe, with greater investment in research and development. Since 2004, the European Defence Agency has successfully led this process, and should continue to do so. ${ }^{84}$

Even if limited institutionally, it seems the EDA has not only slowly guaranteed the trust of its Member States but has also been able to develop, sustain and disseminate a homogeneous discourse on the political role of the European defence industry.

The EDA is the converging point where the discourse on the national defence industry faces the discourse on the European defence industry. Member States are the "shareholders" of the agency, but, as we have seen, that has not prevented it from developing a European discourse that goes against the national practices that most of these states still engage in. As the current EDA's Chief Executive Alexander Weis stated:

What we lack most is solutions at the European level instead of continuing along the path of finding purely national answers. That is the Agency's

80. Nick Witney, “The EDA's Goals: Strengthening Europe's Capabilities and Defence Industrial Base", Speech at the European Institute's Transatlantic Roundtable on Defence and Security, Washington, DC, 14 February 2007.

81. Ibid., p. 32.

82. Ulf Hammarström, "A Strong European Defence Industry: What Needs to be Done?", RUSI Defence Systems (June 2008), p. 90.

83. European Defence Agency, “EU Governments ask EDA for Armaments Strategy, Agree Steps for More Defence Collaboration", Press Release, EDA (9 April 2008).

84. European Council, Report on the Implementation of the European Security Strategy-Providing Security in a Changing World (Brussels, 11 December 2008). 
mission and I will engage myself fully in the next few years to increase European cooperation on capabilities, R\&T, armaments and industry. ${ }^{85}$

However, these national dynamics are still present in the agency. The two most important Member States in this field, the United Kingdom and France, have different ideas about what the EDA should be about. Whereas "London remains more interested in inter-operability and strengthening capabilities", 86 for "France, the EDA is a platform to create a European defence manufacturing base, supported by more spending on $R \& D$ and with contract preferences for European firms" ${ }^{87}$

This tension between the national and the European has led to the situation in which governments accept both the market and the European logics, while at the same time keeping some of the old practices. As Nick Witney makes clear:

Governments generally insist that it is up to industry leaders to consolidate their companies according to commercial considerations. But the same politicians use taxpayers' money to try to ensure that, when the inevitable industry contraction and consolidation occurs, their own "national champion" is among the last men standing. ${ }^{88}$

Could this just be the swan song of the national defence industry's discourse, or the persistence of the same logic, mutated into a hybrid national-European system, where both discourses and dynamics co-exist? As Eliassen and Sitter highlight: "[a]rticle 296 is hardly at risk, but the very establishment of the EDA can be seen partly as a consequence of the shifting consensus on this matter, and partly as a signal that further steps are likely to be taken." 89

\section{A Matter of Scale}

As seen previously, the creation of the EDA was a further step in the solidification of a strong and coherent European discourse in favour of the establishment of both an integrated European industrial base and a common European market. These steps can be framed as part of a wider EU ambition to establish itself as a true global actor, capable of assuming the responsibilities of both its economic power and historical legacy. For that, the European Union has undertaken a series of measures that replicate state sovereign prerogatives at the European level: a common currency, a common border and now a common industrial defence base.

So far, the European Union's role in the world has been one of change and uniqueness in which a strong normative dimension ${ }^{90}$ was combined with more traditional international roles. However, by pointing out the existential need for

85. Alexander Weis, "Introduction", European Parliament. Subcommittee on Security and Defence (10 January 2008).

86. Eliassen and Sitter, op. cit., p. 16.

87. Guay, The Transatlantic Defense Industrial Base, op. cit., p. 13.

88. Witney, Re-energising Europe's Security and Defence Policy, op. cit., p. 38.

89. Eliassen and Sitter, op. cit., p. 13.

90. Manners, op. cit. 
a European defence industry, the European Union's novelty seems to be merely a matter of scale than of a true alternative position on the international stage.

The opacity of relations between state and industry regarding issues of defence and security is traditionally problematic in terms of democratic accountability, often leading to unclear behaviours, such as the recent bribery allegations involving BAE Systems, the British government and Saudi Arabia. ${ }^{91}$ These result from a particular security perspective in which these companies have a central role to play in guaranteeing a state's national security, despite their increasingly transnational outlook. Following the Copenhagen School's security theory, it could be argued that these companies are part of an economic-sector securitisation in which their existence is seen as crucial for a state's own survival. ${ }^{92}$ However, as the theory also says, these securitisation processes involve the upgrading of an issue from the political sphere to a security sphere in which the public utterance of security concerns leads to a lack of public accountability as the issue is dealt with by a restricted number of security actors. ${ }^{93}$ Thus, ideally, in the name of politics and public discussion, issues should not be dealt with under a security labelling, but rather through "normal" political means.

By attempting to amplify state-industry relations in the sphere of defence to the European level, the European Union is accepting the logic of this relation as it stands: a logic that ultimately understands the world as a realm of power politics, self-help, and survival. By accepting this, the European Union defines its own international positioning as a nation-state would do, thus bringing little in terms of innovative ways for the understanding of international politics. As a consequence, its (the European Union's) normative credentials are outweighed by the replication of states' behaviours at the European level. The promotion of a new type of international politics is constrained by classic security concerns, and the Realist thinking that underlines state-industry relations in the field of defence is transferred to the EU level. In short, it follows the same logic, at a different (European) scale.

\section{Conclusion}

As seen throughout this article, the creation of the EDA is just the latest step in the political legitimisation of a European integrated defence industrial base. This is a process that has claimed and transposed some of the existential national arguments to the European level. In order for the European Union to be a credible international actor, with a levelled relationship with its major international allies (namely the United States), to be an efficient, economically and technologically developed quasi-polity, and to guarantee its own existence in the face of the unknown world "out there", it needs, according to this discourse, a European integrated defence industry.

Despite the historical and institutional differences between the European Union and its Member States, there seems to be a parallel rationale towards the need to justify the appropriation of the control over the defence industries on the basis of

91. David Leigh and Rob Evans, "BAE admits Guilt over Corrupt Arms Deals", The Guardian (6 February 2010).

92. Barry Buzan, Ole Wæver and Jaap de Wilde, Security: A New Framework for Analysis (Boulder: Lynne Rienner, 1998).

93. Ibid. 
an existential discourse. In that sense, the European Union does not bring anything new in terms of the role of these industries. On the contrary, it helps reify the underlying rationale behind their political legitimacy: one related to an understanding of the world as largely anarchical, in which its main units need to find the means to guarantee its own military survival. The debate between controlling these industries at the national or European level is thus a debate that focuses on scale rather than on purpose: it focuses on whether these industries should be under national or European control, rather than on how and to what extent they are relevant in our contemporary world, leaving the political "existential" condition attached to these industries untouched. 